\title{
Back to the Roots a)
}




\section{Nature, Society, and Culture}

SCOTT FRICKEL, SERIES EDITOR

A sophisticated and wide-ranging sociological literature analyzing nature-society-culture interactions has blossomed in recent decades. This book series provides a platform for showcasing the best of that scholarship: carefully crafted empirical studies of socioenvironmental change and the effects such change has on ecosystems, social institutions, historical processes, and cultural practices.

The series aims for topical and theoretical breadth. Anchored in sociological analyses of the environment, Nature, Society, and Culture is home to studies employing a range of disciplinary and interdisciplinary perspectives and investigating the pressing socioenvironmental questions of our time-from environmental inequality and risk, to the science and politics of climate change and serial disaster, to the environmental causes and consequences of urbanization and war making, and beyond.

For a list of all the titles in the series, please see the last page of the book. 


\title{
Back to the Roots ga
}

\author{
Memory, Inequality, and \\ Urban Agriculture
}

Sara Shostak

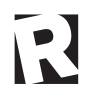

RUTGERS UNIVERSITY PRESS

NEW BRUNSWICK, CAMDEN, AND NEWARK, NEW JERSEY, AND LONDON 
Library of Congress Cataloging-in-Publication Data

Names: Shostak, Sara, author.

Title: Back to the roots: memory, inequality, and urban agriculture / Sara Shostak.

Description: New Brunswick: Rutgers University Press, [2021] | Series: Nature, society, and culture | Includes bibliographical references and index.

Identifiers: LCCN 2020035570 | ISBN 9780813590141 (paperback) | ISBN 9780813590158 (cloth) | ISBN 9780813590165 (epub) | ISBN 9780813590172 (mobi) | ISBN 9780813590189 (pdf)

Subjects: LCSH: Urban agriculture-Massachusetts.

Classification: LCC S494.5.U72 S56 2021 | DDC 630.9173/209744-dc23

LC record available at https://lccn.loc.gov/2020035570

A British Cataloging-in-Publication record for this book is available from the British Library.

Copyright (c) 2021 by Sara Shostak

All rights reserved

No part of this book may be reproduced or utilized in any form or by any means, electronic or mechanical, or by any information storage and retrieval system, without written permission from the publisher. Please contact Rutgers University Press, 106 Somerset Street, New Brunswick, NJ 08901. The only exception to this prohibition is "fair use" as defined by U.S. copyright law.

(ब) The paper used in this publication meets the requirements of the American National Standard for Information Sciences-Permanence of Paper for Printed Library Materials, ANSI Z39.48-1992.

www.rutgersuniversitypress.org

Manufactured in the United States of America 
For my beloved, Matt Glaser 
